\title{
Inter-sectoral network to face violence against children and adolescents in a rural context
}

\author{
Rede intersetorial para o enfrentamento da violência contra \\ crianças e adolescentes em contexto de ruralidade
}

Red intersectorial para enfrentar la violencia contra niños y adolescentes en un contexto rural

\section{Lina Domenica Mapellia \\ Fabiano Henrique Oliveira Sabino ${ }^{a}$ \\ Luiza Cesar Riani Costa ${ }^{a}$ \\ Jorge Luiz da Silvab \\ Maria das Graças Carvalho Ferrianic Diene Monique Carlos ${ }^{a}$}

\section{How to cite this article:}

Mapelli LD, Sabino FHO, Costa LCR, Silva

$J L$, Ferriani MGC, Carlos DM. Inter-sectoral network to face violence against children and adolescents in a rural context. Rev Gaúcha Enferm. 2020;41:e20190461. doi: https://doi.org/10.1590/19831447.2020.20190461 a Universidade Federal de São Carlos (UFSCar), Centro de Ciências Biológicas e da Saúde, Departamento de Enfermagem. São Carlos, São Paulo, Brasil.

- Universidade de Franca (UNIFRAN), Programa de Mestrado e Doutorado em Promocão de Saúde. Franca, São Paulo, Brasil.

Universidade de São Paulo (USP), Escola de Enfermagem de Ribeirão Preto, Departamento de Enfermagem Materno-Infantil e Saúde Pública. Ribeirão Preto, São Paulo, Brasil.

\section{ABSTRACT}

Objective: To analyze the Primary Health Care inter-sectoral network in a rural context to face domestic violence against children and adolescents.

Method: A qualitative research study, with the Paradigm of Complexity as theoretical and methodological framework. Eighteen health professionals from two rural Family Health Units in a municipality in the state of São Paulo were the participants. Data was collected through minimum maps of the institutional network and focus groups in May and June 2019. Data was analyzed through thematic analysis.

Results: Two categories emerged, entitled "It's not nonexistent, but it's complicated" and "We're always on the firing line". The existence of a weakened network; assistance based on biomedical bias; and care fragmentation were characteristics present in the care provided to the families.

Final considerations: The absence of network care was evident, with isolation and overload of the Primary Health Care unit that is enhanced by the characteristics of rurality.

Keywords: Domestic violence. Child. Adolescent. Social networking. Primary health care. Rural health services.

\section{RESUMO}

Objetivo: Analisar a rede intersetorial construída a partir da Atenção Primária à Saúde em contexto rural para enfrentamento da violência doméstica contra crianças e adolescentes.

Método: Pesquisa qualitativa, tendo como referencial teórico e metodológico o Paradigma da Complexidade. Participaram dezessete profissionais de saúde de duas Unidades de Saúde da Família rurais de um município de São Paulo. Os dados foram coletados por meio de mapas mínimos da rede institucional e grupos focais, em maio e junho de 2019; foram analisados tematicamente.

Resultados: Emergiram duas categorias intituladas "Não é inexistente, mas é complicada" e"A gente está sempre na linha do tiro". A existência de uma rede fragilizada; a atenção pautada pelo viés biomédico; a fragmentação no cuidado foram características presentes no cuidado às famílias.

Considerações finais: a ausência de um cuidado em rede ficou evidente, gerando isolamento e sobrecarga da unidade de atenção básica que é potencializada pelas características da ruralidade.

Palavras-chave: Violência doméstica. Criança. Adolescente. Rede social. Atenção primária à saúde. Serviços de saúde rural.

\section{RESUMEN}

Objetivo: Analizar la red intersectorial construida a partir de la Atención Primaria de Salud en un contexto rural para hacer frente a la violencia doméstica contra niños y adolescentes.

Método: Investigación cualitativa, teniendo como marco teórico y metodológico el Paradigma de la Complejidad. Participaron dieciocho profesionales de la salud de dos unidades rurales de salud familiar en un municipio del estado de San Pablo. Los datos se recopilaron a través de mapas mínimos de la red institucional y grupos focales en mayo y junio de 2019; y fueron analizados temáticamente.

Resultados: Surgieron dos categorías tituladas "No es inexistente, pero es complicado" $y$ "Siempre estamos en la línea de tiro". La existencia de una red debilitada; la atención basada en el sesgo biomédico; y la fragmentación de la atención fueron características presentes en el cuidado de las familias.

Consideraciones finales: La ausencia de atención en red fue evidente, lo que generó aislamiento y sobrecarga de la unidad de atención primaria que se ve reforzada por las características de la ruralidad.

Palabras clave: Violencia doméstica. Niño. Adolescente. Red social. Atención primaria de salud. Servicios de salud rural. 


\section{INTRODUCTION}

Children and adolescents can face the violation of their rights in their own homes, emerging as the main context of violence against this population; this violence, called domestic violence, usually occurs from people with affective ties, consanguineous or not, with this population ${ }^{(1)}$. Violence is understood as the intentional use of force or physical power, real or threatening, against a person, group or community, which results or is likely to result in injury, death, psychological harm, deprivation or developmental change ${ }^{(2)}$. In Brazil, child and youth deaths from accidents and violence are in third place, second only to cases of perinatal complications and malformations ${ }^{(3)}$.

Primary Health Care (PHC) presents itself as a strategy for reorganizing the health service system, placing itself as an articulation axis in the care of the population's health problems, including domestic violence ${ }^{(4)}$. In this context, the Ministry of Health proposes the integration of resources (actions and institutions) available to face violence in a care network, guided by $\mathrm{PHC} \mathrm{C}^{(1,4)}$.

PHC comprises one of the main points of the inter-sectoral network for the protection of children and adolescents. The whole process comes from the principle that PHC is the coordinating center of care, including the gateway to receive cases of violence. The articulation of this sector with the others allows a more natural and constant flow for the phenomena of referencing and counter-referencing ${ }^{(1)}$. Still in this context, the inter-sectoral network is composed of professionals and institutions whose main purpose is to protect and guarantee the rights of children and adolescents. It comprises the sectors of public security, the third sector, education, and culture, among others ${ }^{(2)}$.

Facing domestic violence against children and adolescents presents numerous challenges for identification, management, and prevention ${ }^{(1,5-7)}$; this fact is aggravated in some contexts, such as the rural area. Care for the populations living in a rural context has been presented by the literature as a space of social and scientific vulnerability ${ }^{(8-10)}$. The first is due to the greater difficulty in the access to and coverage of health and other services such as education, generating lack of opportunities and possibilities ${ }^{(8-9,11)}$. A history of singularities, anonymity, and isolation also exposes these populations to greater violence, adding to the vulnerabilities of some categories such as children and adolescents ${ }^{(10)}$. Seeking to face unfavorable health conditions and health inequalities in this population, the Ministry of Health institutes Ordinance No. 2,866/2011 within the scope of the Unified Health System, which addresses the
National Policy for Comprehensive Health of the Rural and Forest Populations ${ }^{(11)}$; despite the progress, the transposition of this policy into practice is still a challenge. The second vulnerability, related to the scientific realm, refers to the scarcity of studies and interventions in this scope. This fact reinforces the invisibility of these populations that are little studied and legitimized, despite constituting $16 \%$ of the Brazilian population ${ }^{(8)}$.

Considering the above, the present study awakens us to the following questions: What are the actions developed by the PHC services to face domestic violence against children and adolescents, considering the rural context? What are the institutional links established by these services for carrying out such actions? The answers to these questions will be found based on the Complexity Paradigm, which addresses what is "woven together", which implies considering the different, and sometimes contradictory, parts that are articulated in the composition of the phenomenon, inserted in a context, from a dialogical perspective. For this, a polyocular view of the phenomenon becomes necessary ${ }^{(12)}$.

In the PHC environment, the Nursing team represents itself as an active agent in the defense of the rights of children and adolescents. For this, the nurse must qualify as a professional to properly handle all the complexity of the violence process together with the multidisciplinary team ${ }^{(13)}$. The authors reinforce that the quality of Nursing care is based on its communication with other professionals and services in the network, avoiding individualization of work and gaps in partnership relationships ${ }^{(13)}$.

In addition to the positive contributions to the family, when well-articulated, the network ensures the work efficiency of the professional who deals with cases of violence, facilitating the care process, culminating directly in the quality of life of those involved by it ${ }^{(13-14)}$, especially in a context that is in itself marginalized, such as the rural. Therefore, the objective is to analyze the inter-sectoral network built from $\mathrm{PHC}$ in a rural context to face domestic violence against children and adolescents.

\section{METHODS}

The present research work was designed based on a qualitative approach of the exploratory and descriptive type, which allows us to understand the reality expressed by the participants in their natural context ${ }^{(15)}$. The Complexity Paradigm was used as a theoretical and methodological framework; it does not seek to cut or reduce the aspects involved in a phenomenon, but to observe them in an articulated manner ${ }^{(12)}$. The dialogical (coexistence of oppositions 
and antagonisms at the same time); recursive (products and effects are causes and producers of what produced them, at the same time); and retroactive (causes act on effects and effects act on causes) principles guided data collection and analysis ${ }^{(12)}$.

The study field was a municipality in the inland of São Paulo, which has 220,578 inhabitants ${ }^{(16)}$. Two Family Health Units (FHUs) from two districts located to the North of the municipality in a rural area, nearly 12 and $30 \mathrm{~km}$ from the center of the municipality, were included. The population living in these regions was approximately of 6,000 people, distributed equally in the two districts. The population of children and adolescents totals nearly $23 \%$ of the inhabitants. They have two municipal schools for early childhood education and three state schools for elementary and high school education; a Social Assistance Reference Center. and two community centers ${ }^{(16)}$. The choice for these units is justified by the particularities of rurality, being the only ones in the municipality located in the rural context. The study participants were health professionals from these units, considering the following inclusion criteria: (i) professionals who have been in contact with families involved in violence against children and adolescents in primary care; (ii) professionals who have worked in the units that were studied for at least one year. Participants who were away from the service during the period of data collection due to vacation or medical and legal leave were excluded.

The encounter between the units and the professionals occurred in March 2019, by means of the participation of the first and last authors and researchers in a team meeting. On this occasion, the research objectives, the inclusion and exclusion criteria, and possible study contributions to the practice were presented. The first unit, entitled as A, was quite receptive as it marked a great need for studies in the area of violence; the second, entitled as B, said it was a theme that was not very present in its daily life, but agreed to participate. It should be noted that the first unit has greater contact with the university, by offering extension projects and curricular internships. Of the total of 32 health professionals who worked in the units, ten were on vacation or other leave; and five reported not having dealt directly with the situations of violence mentioned during this initial approach. Thus, there were 17 participants, ten in Unit A and seven in Unit B.

Data collection took place in the months of April and May 2019 through the elaboration of minimal maps of the external institutional social network ${ }^{(17)}$ and focus groups ${ }^{(18)}$. Initially, each professional answered a questionnaire with social and demographic data. This collection was carried out in the team meeting space in each unit, according to the professionals' preference. In Unit A it was conducted in two meetings, with a mean duration of 40 minutes each - the minimum map was built in one meeting and the following week, the focus group was held in a single meeting. In Unit $\mathrm{B}$, collection was carried out in a meeting lasting 83 minutes; the map was constructed, and the focus group was carried out later. Collection organization followed the scheduled time for the team meeting in each unit.

The minimum map aims to identify and assess the quality of the institutional links between the unit under study and the formal or informal institutions for network care ${ }^{(17)}$. It is represented by a circle with quadrants around it, which indicate the existing sectors for this care, such as education, health, legal area, security, religion, environment, work, leisure, culture, social assistance, and families, among other sectors suggested by the units ${ }^{(17)}$. These maps allow understanding the way in which the relationships are established. They are delineated through lines with different strokes, which graphically represent the links between the families and the individuals/institutions, and can be of three types: significant - black lines; fragile - dotted lines; and broken or nonexistent - gray lines ${ }^{(17)}$.

For the elaboration of the minimum maps, the participants were presented with the same printed material on an A5 sheet and the way of construction, with the specifics of the strokes. The possibility of including institutions and/or sectors was emphasized based on the participants' decision, and that the network would be built from what people experienced, and not from what was idealized. The evaluation of the design of the maps is carried out using the following criteria: size (number of institutional or personal links established, the network being classified as reduced, medium or extended); density (quality of the links observed with respect to the stroke lines: significant, fragile, broken and/or nonexistent); distribution/composition (number of people or institutions located in each quadrant, with the possibility to identify weaknesses and potentialities of the network based on this criterion); dispersion (geographical distance between the participating individuals or institutions and the others located on the maps); homogeneous or heterogeneous (diversities and similarities of the individuals and/or institutions present in the network) ${ }^{(17)}$.

The focus groups, which aim to collectively listen to the individuals and to observe their interactions ${ }^{(18)}$, had the following guiding questions: What actions are taken by the unit to care for the families involved in violence against children and adolescents? How is the articulation among other services for this care? The elaboration of the maps and the realization of the focus groups were marked out by the first and last researchers and authors of this study, 
them being the observer and moderator, respectively. The meetings were recorded using a voice recording application and transcribed manually.

After the graphical elaboration of the maps and full transcription of the focus groups, the stages of thematic analysis were conducted ${ }^{(19)}$, namely: classification and organization of the information; organization of the referential frameworks; and establishment of relationships between the data. The principles of the Complexity Paradigm were applied in the last two stages, for data interpretation and articulation. Two final referential frameworks were built: the first, "It's not nonexistent, but it's complicated" and the second, "We're always on the firing line". The construction of the referential and final frameworks is shown in Chart 1.

According to the ethical recommendations for research studies with human beings, contained in Resolution No. 466/2012, the study was approved by the Ethics Committee in Research with Human Beings of the Federal University of São Carlos under opinion number 3,163,630 on February $22^{\text {nd }}, 2019$. In addition, it was authorized by the Municipal Health Secretariat and by the units' local coordination. The professionals agreed to participate in the study by signing the Free and Informed Consent Form. To ensure the anonymity of the participants, the names of the professionals were identified with the letter $P$ and numbered from the speech sequence (P1, P2, and so on).

\section{RESULTS}

Seventeen professionals participated in the study: two nurses, three nursing technicians, nine community health workers, a physician, a dentist, and a pharmacy technician. Among the participants, two were men and fifteen were women; two professionals were between 20 and 30 years old; seven were between 30 and 40 years old; four were between 40 and 50 years old, and four were between 50 and 60 years old. Six professionals had higher education, with two having some lato-sensu specialization and one, a Doctorate. Five of these professionals have attended training courses on violence in the past five years

In the analysis of the minimum map, Unit A presented a reduced network, not very dense, with a large number of fragile or broken links. Two services were scored as significant, the Social Assistance Reference Center (Centro de Referência de Assistência Social, CRAS) and the children's school, which were geographically close to the unit. Such map can be seen in Figure 1.

Unit B presented a reduced network, not very dense, as it has only one significant link and a large number of missing links. Gaps were perceived in several sectors, with a considerably homogeneous institutional network, focusing only on the education and social assistance links. This map is illustrated in Figure 2.

\section{Initial frameworks}

Final frameworks

Conflicts in the relationships

Absence of significant links

No knowledge of services

Logic of the referencing

Informality

Little articulation

Little resoluteness

Not knowing the dynamics of violence

Institutional isolation

Ambivalence in the actions

Frustration, sadness

It's not nonexistent, but it's complicated

We're always on the firing line

Chart 1 - Initial and final referential frameworks. São Carlos, 2019 


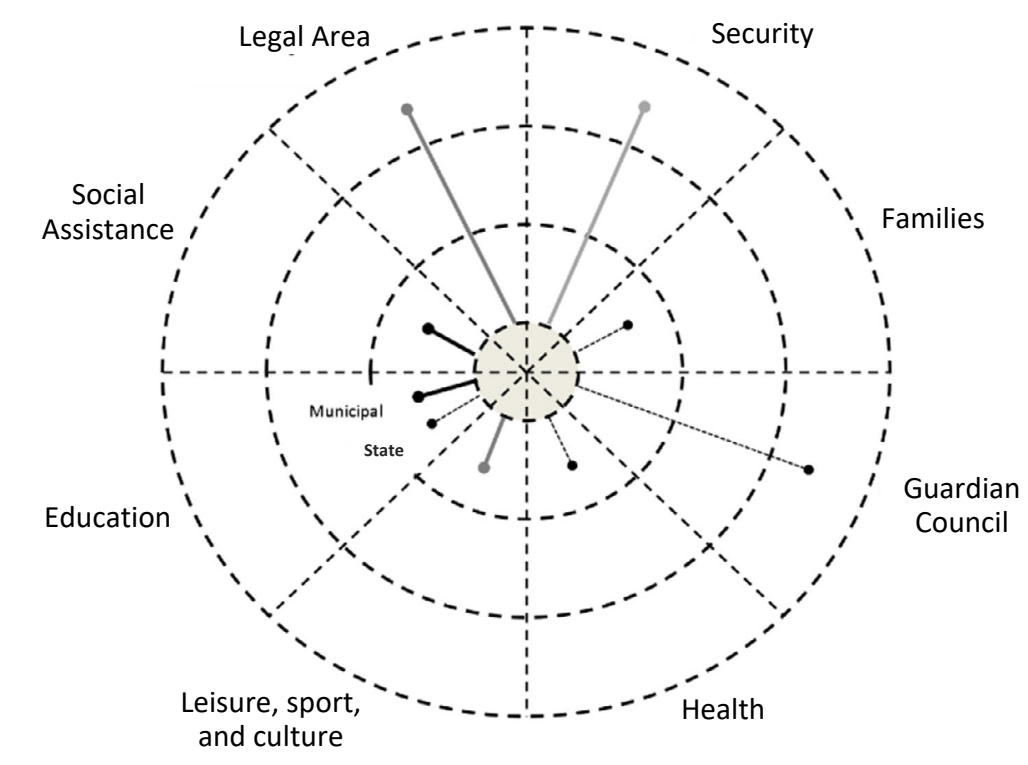

Key

$\longrightarrow$ Meaningful links $\quad \ldots .-\ldots-.$. Weakened links $\quad \longrightarrow$ Broken or nonexistent links

Figure 1 - Minimum Map of the External Institutional Social Network of Unit A. São Carlos, 2019.

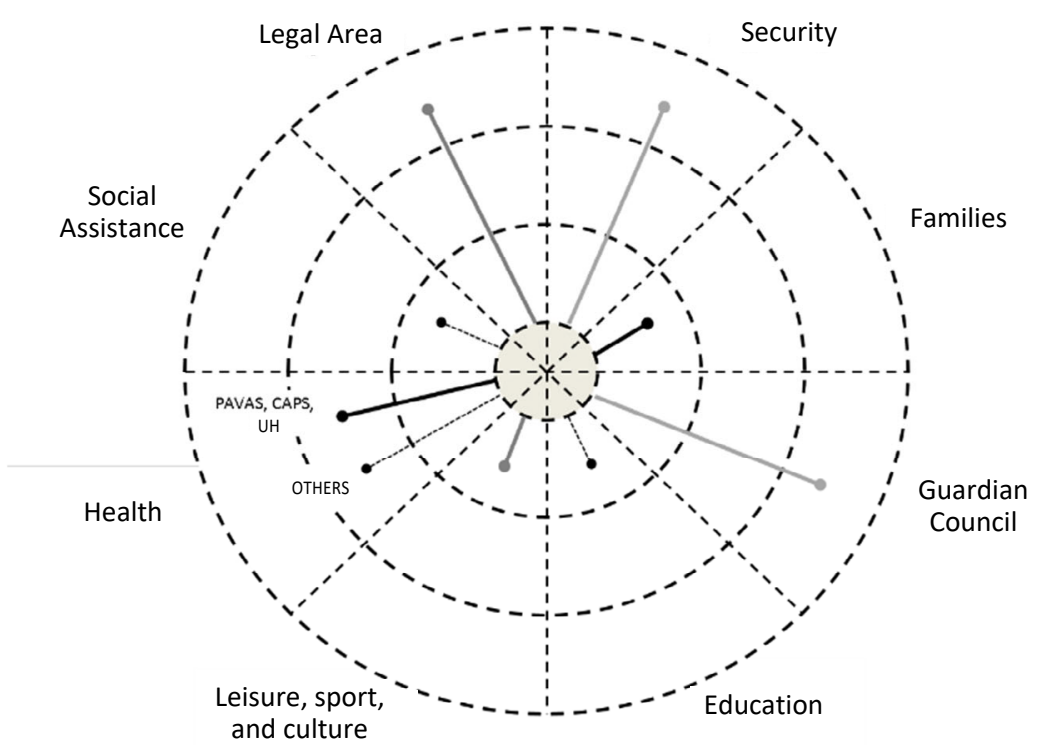

Key

Figure 2 - Minimum Map of the External Institutional Social Network of Unit B. PAVAS - Assistance Program for Victims of Sexual Violence (Programa de Atendimento a Vítimas de Violência Sexual); CAPS - Psychosocial Care Center (Centro de Atenção Psicossocial); UH - University Hospital. São Carlos, 2019. 


\section{Referential framework 1 - It's not nonexistent, but it's complicated}

The speeches permeated the non-harmonious relationships between the units and the other services of the child and adolescent protection network.

[...] The situation with the CAPSi is chaos, they say they can refer the user to the reception, but when the case gets there, the psychological care services are restricted... The users remain here, without due care, we don't know how to act and there are also no feedback for the cases. (P2) [About the relationships with hospitals] But this is not a relationship that is nonexistent, but it's complicated. (P1)

A network that worked, that got articulated, that talked... a little that existed is over. (P10)

In view of the delimitation of the minimum map of the units under study, the presence of links characterized as unidirectional, punctual and centered on people was observed, with non-institutionalized relationships. The lack of knowledge of the roles played by all the support and constituent services of the Network was also highlighted.

I've never seen the actions of the Guardian Council, so much so that when these cases of violence happen, we really don't know who to turn to, how we're going to deal with these people. [...] (P3)

[About actions in community centers] sometimes there's a ball championship, something like that, but I don't know if there are other activities like that... (P9)

A "referencing logic"was denoted between professionals and other institutions. This logic generated low resoluteness of the difficulties and inefficiency of the care offered, still guided by the biomedical bias. The perception that violence was a demand for "mental health" professionals was also reinforced.

So I thought it was better to refer to the specialty center, because there I know that when they have these cases, people receive psychological counseling. (P5)

[About referencing cases of children and adolescents victims of violence to mental health services] It's just that our relationship is more of referencing, we refer there and they usually take care of the service. (P7)

Regarding the referencing-counter-referencing process, flaws were verified in the execution of this resource due to the fact that the information reached the institutions informally or was lost in the process, with no formal strategy that guaranteed feedback and the continuity of the care provided.

It's not formal at all, it's the guy who heard a murmur somewhere, who told someone else, who in turn comes to be seen here, and tells us what happened, and we don't know how much is true or not and we don't know how much can we find out, how far can we go? (P6)

[...] The unit tries to calm the situations momentarily so as not to complicate the psychological health of the child and adolescent, but it doesn't have a conclusion of the case, nor a long-term follow-up, both on our part, and for the other institutions in the municipality. (P13)

Although weakened, the units under study showed links with specific people and services that are geographically close, as is the case with Unit A, which maintained a significant relationship with the social assistance team.

We have a lot of contact with the social worker, she's always here in the unit when we need or we call her when we have any questions [...] the good thing is the CRAS where she's located is close to us, we don't have to go to São Carlos to get in contact with her. [...] (P8)

I think that, in my idea it would be her because she's here... I think that's why we have the greatest link, right? (P4)

\section{Referential framework $\mathbf{2}$ - We're always on the firing line}

It was verified that the "perspectives of the units"remained closed to the dynamics of violence, even with the understanding of this phenomenon through the physical bias, of physical aggression. The determining elements present in this phenomenon have still been little recognized:

[...] If we stop to think, we have few cases of violence here in the unit, because for me, the first thing that comes to my mind when I think of violence are physical aggressions. (P10)

[...] The unit team and the population don't understand that violence does not only represent physical aggressions, there are verbal and psychological aggressions as well, which hurt as much as physical aggressions. (P12)

Care in the face of situations of child and youth violence in the units under study was carried out through more healing 
and less preventive interventions; there was no sharing of actions with other institutions and their members. The silence and the attempt to "avoid" cases were noticed, as a result of the units not knowing how to proceed in the face of the violation of the rights of children and adolescents and feeling isolated. The professionals reported feelings of fear, frustration, and helplessness in the teams interviewed. Frustrations and questions emerged about remaining "with their hands tied" when confronting the multiple faces of violence:

[...] There was a case that needed the intervention of the Guardian Council, then that "confusion" is formed and the unit becomes the center of attention, but after fame is over: what is the solution? How do we go about solving it? They leave and we stay! (P11)

When I assist, I usually ask if the person has already experienced some type of violence, but there are times when I don't even ask, because the person has already collapsed and cried there for an hour, without stopping. [...] I keep thinking, why asking? Suddenly, it's better to remain silent. (P14)

I think the word with which I can summarize the situation of violence in our community is sadness, sadness for the children, adolescents and family members and because we aren't able to do much, it seems that nothing is solved. (P16)

The excerpt "They leave and we stay" reinforced the issue of isolation and the feeling of "institutional solitude" experienced by the teams. The geographical and territorial distance of the units was mentioned by the interviewees as a complicating factor in solving cases of violence, as they mentioned that they were distant from "civilization", understanding that being in the urban perimeter facilitated the search for care options for the population.

The units recognized and organized themselves as Emergency Care Units, aimed at solving situations through the "complaint-conduct" process. According to the participants, the users of the units also had controversial views on the purpose of PHC.

[...] There are people from the city who call and ask if there's a doctor seeing cases here, if it's taking too long [...] The place ends up becoming urgent and emergency care services for these people, for the people in the community and the health promotion, prevention and education activities are not adhered to when proposed. (P9)
And there's a lot of service and we aren't able to do other actions... like a club that would work well in these ages... (P16)

The professionals mentioned that the rural communities valued the physical space of units A and B, as they saw them as a space for social interactions. Thus, there was certain ambivalence in the interviewees' statements, as they mentioned that the communities did not seek prevention and health promotion actions, but that they noticed the absence of leisure and socialization spaces for the population.

One thing that is lacking in our community are activities for the population, I think that if there was something for people to do, it would even reduce the number of services in the unit. [...] / have the impression that the population comes here to chat. [...] If you come here, on Mondays or Tuesdays in the morning, it doesn't even look like a health unit, it looks like a Sunday market. (P15)

Before there was an education and health group, it was very nice, we did it with the children, we had very nice feedback there... so the children were multipliers, for the parents, so we had the parents', the teachers'feedback... (P17)

\section{DISCUSSION}

The referential frameworks "It's not nonexistent, but it's complicated" and "We're always on the firing line" particularly unveiled the weaknesses of the care provided to families involved in domestic violence against children and adolescents in the rural context under study. A number of characteristics of the simplification paradigm ${ }^{(12)}$ appeared in the professionals' discussions: assistance guided by the biomedical bias; fragmentation in care, whether due to the lack of recognition of the institutions that configure the network or to a logic based on referencing; and lack of awareness-raising for the complexity of phenomena such as violence. Inseparable issues, such as the particular, singular, and dynamic form of rural territorial identity are raised only by geographical distance ${ }^{(12)}$.

It was identified that there is no care network for domestic violence, herein understood as a complex phenomenon, that is, intertwined with multiple elements ${ }^{(12)}$. To act in the face of violence and other contemporary phenomena, since the $20^{\text {th }}$ century new paradigms have been seeking to overcome the fragmentation of thought and actions, with the dissemination of an integrating and multidimensional view of mankind and its environment ${ }^{(12)}$. In this sense, the 
territory needs to be considered beyond the geographic cut, since it is understood as dynamic and alive, expressed in the social relations and productions ${ }^{(11)}$. Considering the context of rurality, singularities and specificities were identified that condition the organization of the health services and practices; among these, geographical isolation stands out ${ }^{(8-9)}$. The literature indicates that PHC still performs poorly in rural areas; has weaknesses in participation and social control; territorialization has not yet been carried out in order to understand the socio-health spaces at greatest risk $^{(9)}$. Despite the National Policy for Comprehensive Health of Rural and Forest Populations ${ }^{(11)}$ having been designed to guarantee the principle of equality in health, it is not present or legitimate in the FHUs under study.

The presence of links characterized by being unidirectional, punctual and centered on people, with non-institutionalized relationships, corroborates previous studies carried out in an urban area ${ }^{(1,6)}$. It is understood that these issues were aggravated by the elements already mentioned, inherent to rurality. The non-return of shared situations or "cases" did not respect feedback, that is, it did not motivate or allow for the analysis and emergence of new and creative interventions based on the interaction among institutions and sectors ${ }^{(12)}$.

There is consensus in the literature that care for complex phenomena, such as domestic violence against children and adolescents, requires an interdisciplinary and inter-sectoral articulation $^{(1,3,6,10)}$. In the rural context, this fact is even more necessary; access and accessibility, as well as equality, longitudinality, and integrality in care, extrapolate the existence of an FHU in the territory due to the social determination of the health-disease process of this population ${ }^{(9)}$. Some conditionalities such as the distance from the rural towns to the FHU; road conditions and means of transportation; and lack of access to means of communication, appear as relevant ${ }^{(9)}$. In addition, the absence of cultural and leisure services revealed greater difficulties for actions to prevent violence in general and to promote a culture of peace. Despite this aspect emerging only in Unit A, the fact that geographically close links are positive facilitated the sharing of longitudinal actions, as well as the population's access.

In agreement with the results of the present study, the analysis of the approach of cases of domestic violence against children and adolescents by nurses, in PHC, revealed that the Nursing habitus is still strongly anchored to the biomedical model, with structuring its know-how by means of these components. The approach to situations that are not intelligible by this bias has been neglected ${ }^{(5)}$. A number of studies have corroborated these finding $s^{(1,6-7,14)}$. Despite the advances we had in the appropriation of violence by the health area, the professionals presented internal content difficulties for handling and facing situations of domestic violence; they felt uncomfortable with the fact that it was a complex phenomenon, of a difficult outcome, and without a clear and linear cause-effect-resolution relationship ${ }^{(1,6,14)}$. Still in this context, a study demonstrated that looking at concrete situations, in the case of violence characterized by the presence of physical elements, was more present than the action in relation to other types of violence $e^{(7)}$.

A study developed with Australian nurses to explore the care provided to families with complex needs (mental disorders; histories of trauma such as violence and substance use) identified that, to effectively support these families, the professionals need permanent education and clinical supervision ${ }^{(20)}$. Such action is essential to expand the knowledge and understanding of the diversity of family needs and ways to meet them. In addition to this aspect, the authors reinforce that these nurses and teams need support, as this work consumes more resources and time than typical clinical care ${ }^{(20)}$.

On the other hand, it was noticed that institutional isolation, enhanced by the rural context essentially in its geographical characteristic, ended up reinforcing feelings of solitude and helplessness. In this context, solidarity is presented as a fundamental element to overcome the current world crisis, considering the fragmentation of knowledge and beings, as well as impotence in the face of the uncertainties of the contemporary phenomena ${ }^{(12)}$.

As identified by the professionals, many actions in PHC were carried out in the logic of an Emergency Department; this aspect corroborates a study carried out in Campinas-SP, with the same objective as this research ${ }^{(6)}$. The hegemony of fragmented health care systems ends up directing some systems for the care of acute conditions, and of acute events associated with chronic diseases. This fact enhances the cultural perception of devaluation of the PHC functions, as well as of the health promotion and disease prevention actions $^{(4)}$. An essay that sought to problematize the health situation of this population showed that Hospitalizations for Conditions Sensitive to Primary Care are higher in the rural context; such situations are driven by socio-environmental characteristics, but also by the organization of the services, with few or specific actions to promote health and prevent diseases ${ }^{(9)}$.

In this sense, the dialogic ${ }^{(12)}$ expressed by the health professionals was unveiled: they reported that the population perceived the unit as an Emergency Department and, at the same time, signaled that this population used these services 
as "Meeting points", for collective conversations between the community. A retroactive movement ${ }^{(12)}$ was perceived, in which the "natural" organization of the units took place by the immediate logic of urgency and, from that, the population was organized to receive such care. There was little commitment to community empowerment, guaranteeing participation and social control. A study carried out in rural areas of Norway on risks and harms identified by users related to their safety in health services found that they can be quite participatory in issues involving their health, demonstrating reflection and construction of strategies for such ${ }^{(8)}$.

\section{GINAL CONSIDERATIONS}

Resuming the objective of this study, a fragile inter-sectorial network with little effective organization to face domestic violence against children and adolescents was evidenced. It was identified that the rural context deepens the isolation and institutional overburden of the units. Some difficulties reported by the professionals, such as the lack of understanding of the dynamics of violence beyond the biomedical bias and the non-appropriation of units as PHC by the professionals and families, need to be overcome for the network organization.

The main limitations of the study were related to the fact of not looking deeper into the network considering the different professional backgrounds and functions, with consequent differentiated actions; conducting individual interviews could have been a strategy for this deepening. Despite the limitations, it brings contributions to research through the approach of a neglected context, the rural area, which also needs to be incorporated or deepened in the education and training of health professionals.

The organization of practices in PHC that consider the socio-health characteristics of the territory is essential. Furthermore, the understanding of domestic violence against children and adolescents as a complex phenomenon that requires network articulation must be included in Health and Nursing education, in addition to being a theme inherent to the practices, which can be worked on by means of permanent education. In this context, nurses present themselves as primary elements, since they have the necessary knowledge and skills for team management and for interdisciplinary and inter-sectoral care for the population. Further studies are needed to envision the social support network from the perspective of the families involved in episodes of violence, as well as the development of prevention and intervention strategies in the face of these situations through participatory research studies.

\section{REFERENCES}

1. Carlos DM, Pádua EMM, Ferriani MGC.Violence against children and adolescents: the perspective of Primary Health Care. Rev Bras Enferm. 2017;70(1):537-44. doi: https://doi.org/10.1590/0034-7167-2016-0471

2. Violence Prevention Alliance [Internet]. Geneva: World Health Organization; c2014- [cited 2019 mar 20]. Definition and typology of violence; [about 1 screen]. Available from: http://www.who.int/violenceprevention/approach/ definition/en/

3. Malta DC, Mascarenhas MDM, Silva MMA, Carvalho MGO, Barufaldi LA, Avanci $J Q$, et al. The occurrence of external causes in childhood in emergency care: epidemiological aspects, Brazil, 2014. Ciênc Saúde Coletiva. 2016;21(12):3729-44. doi: https://doi.org/10.1590/1413-81232 0152112.17532016

4. Mendes EV. As redes de atenção à saúde. Ciênc Saúde Coletiva. 2010;15(5): 2297-305. doi: https://doi.org/10.1590/S1413-81232010000500005

5. Aragão AS, Ferriani MGC, Vendruscolo TS, Souza SL, Gomes R. Primary care nurses' approach to cases of violence against children. Rev Latino-Am Enferm. 2013;21(spec.):172-9. doi: https://doi.org/10.1590/S0104-1169201 3000700022

6. Carlos DM, Pádua EMM, Silva LMP, Silva MAl, Marques WEU, Leitão MNC, et al. The care network of the families involved in family violence against children and adolescents: the Primary Health Care perspective. J Clin Nurs. 2017 Aug;27:2452-67. doi: https://doi.org/10.1111/jocn.13692

7. Egry EY, Apostólico MR, Albuquerque LM, Gessner R, Fonseca RMGS. Understanding child neglect in a gender context: a study performed in a Brazilian city. Rev Esc Enferm USP. 2015; 49(4):556-63. doi: https://doi. org/10.1590/S0080-623420150000400004

8. Harbitz MB, Brandstorp H, Gaski M. Rural general practice patients' coping with hazards and harm: an interview study. BMJ Open. 2019;9:e031343. doi: https:// doi.org/10.1136/bmjopen-2019-031343

9. Pessoa VM, Almeida MM, Carneiro FF. Como garantir o direito à saúde para as populações do campo, da floresta e das águas no Brasil? Saúde Debate. 2018;42(n.spe1):302-14. doi: https://doi.org/10.1590/0103-11042018s120

10. Arboit J, Costa MC, Silva EB, Colomé ICS, Prestes M. Violência doméstica contra mulheres rurais: práticas de cuidado desenvolvidas por agentes comunitários de saúde. Saude Soc. 2018;27(2):506-17. doi: https://doi.org/10.1590/s010412902018169293

11. Ministério da Saúde [BR]. Secretaria de Gestão Estratégica e Participativa. Departamento de Apoio à Gestão Participativa. Política Nacional de Saúde Integral das Populações do Campo e da Floresta. Brasília, DF: Ministério da Saúde; 2013.

12. Morin, E. Introdução ao pensamento complexo. $5^{\text {a }}$ ed. Porto Alegre: Sulina; 2015.

13. Souto DF, Zanin L, Ambrosano GMB, Flório FM. Violence against children and adolescents: profile and tendencies resulting from Law 13.010. Rev Bras Enferm. 2018;71(Suppl 3):1237-46. doi: https://doi.org/10.1590/0034-71672017-0048

14. Galindo NAL, Gonçalves CFG, GalindoNeto NM, Santos SC, Santana CSC, Alexandre ACS. Child and youth violence under the perspective of nursing. Rev Enferm UFPE online. 2017 [cited 2019 Nov 10];11(Suppl3):1420-9. Available from: https://periodicos.ufpe.br/revistas/revistaenfermagem/article/ download/13986/16842 
15. Flick, U. An introduction to qualitative research. 5th ed. Thousand Oaks, CA: Sage; 2009.

16. Instituto Brasileiro de Geografia e Estatística [Internet]. Rio de Janeiro: IBGE; c2020- [cited 2020 Apr 04]. Brasil - São Paulo - São Carlos; [about 1 screen]. Available from: https://cidades.ibge.gov.br/brasil/sp/sao-carlos/panorama

17. Carlos DM, Pádua EMM, Nakano MAS, Ferriani MGC. Minimum Map of Social Institutional Network: a multidimensional strategy for research in Nursing. Rev Esc Enferm USP. 2016;50(n.esp):98-103. doi: https://doi.org/10.1590/ S0080-623420160000300015

18. Kinalski DDF, Paula CC, Padoin SMM, Neves ET, Kleinubing RE, Cortes LF. Focus group on qualitative research: experience report. Rev Bras Enferm. 2017;70(2):424-9. doi: https://doi.org/10.1590/0034-7167-2016-0091
19. Pádua EMM. Complexidade e pesquisa qualitativa: aproximações. Série Academ, PUC-Campinas. 2015 [cited 2019 0ct 11];32(2):39-48. Available from: https:// www.puc-campinas.edu.br/handlers/arquivos/?arquivo $=2596$

20. Rossiter C, Schmied V, Kemp L, Fowler C, Kruske S, Homer C. Responding to families with complex needs: a national survey of children and family health nurses. J Adv Nurs. 2016;73(2):386-98. doi: https://doi.org/10.1111/jan.13146

\section{Acknowledgments:}

To the Institutional Program for Scientific Initiation Scholarships/National Council for Scientific and Technological Development (Programa Institucional de Bolsas de Iniciação (ientífica, PIBIC/CNPq) for the scholarship granted to Lina Domenica Mapelli.

\section{- Corresponding author:}

Diene Monique Carlos

E-mail: diene.carlos@ufscar.br

Associate editor:

Carlise Rigon Dalla Nora

\section{Editor-in-chief:}

Maria da Graça Oliveira Crossetti 